\title{
APPLICATION OF INQUIRY TRAINING LEARNING MODELS WITH MULTIREPRESENTATION OF LEARNING OUTCOMES AND STUDENT PROBLEM SOLVING ABILITIES ON SENIOR HIGH SCHOOL 17 MEDAN
}

\author{
${ }^{1}$ Rina Gunawan Tarigan dan ${ }^{2}$ Nurliana Marpaung \\ ${ }^{1,2,3}$ Department of Physic Education Faculty of Mathematics and Science Universitas Negeri Medan, \\ Indonesia \\ rinatarigan78@gmail.com
}

Accepted: September $5^{\text {th }}, 2020$. Published: October $6^{\text {th }}, 2020$

\begin{abstract}
This study aims to determine the application of the inquiry training learning model with multiple representations of student learning outcomes and problem solving abilities in the subject of Elasticity and Hooke's Law. This study used a quasi experimental method with a two group pretest - posttest research design. The study population was all students of class XI which consisted of 5 classes. The sample was determined by cluster random sampling. Class XI MIA 1 as the experimental class and XI MIA 5 as the control class, each of which consists of 30 students. The instrument used consisted of 10 multiple choice questions for learning outcomes and 5 essay questions for problem solving abilities and had been validated by the validator. The research data shows that the pretest mean value of learning outcomes in the experimental class is 33.00 and the control class was 30.00. Data from the mean pretest of problem-solving ability of the experimental class was 26.22 and the control class was 25.26. The normality and homogeneity tests on the pretest data for the experimental and control classes showed that the data were normally distributed and homogeneous. The $t$ test results showed that the two classes had the same initial ability significantly. After the treatment was carried out in each class, the post-test mean score of learning outcomes in the experimental class was 69.67 and the control class was 58.33. The post-test mean value of problem-solving abilities in the experimental class was 74.52 and the control class was 65.48 . The results of hypothesis testing using the $t$ test on student learning outcomes and problem solving abilities showed that learning outcomes and problem-solving abilities were significantly higher in the experimental class than in the control class. The results of data analysis showed that the inquiry training learning model with multiple representations contributed to the scores obtained by students in the experimental class. It can be stated that the inquiry training learning model with multiple representations has an effect on student learning outcomes and problem solving abilities.
\end{abstract}

Keywords: Inquiry training, multi-representation, learning outcomes, problem solving skills, Elasticity and Hooke's Law. 


\section{Introduction}

The quality of education is a serious agenda at this time to be discussed, both among education practitioners, politicians, society, and policy makers. One of the problems that causes the low quality of education is the weak learning process in Indonesia. Children are less encouraged to develop thinking skills when the learning process and children's abilities are directed to memorize information, children's brains are forced to remember and accumulate various information without being required to understand the memorized information to relate it to everyday life (Sanjaya, 2006).

The author conducted a preliminary study at one of the public high schools in the city of Medan to determine the problems of learning physics in schools. Based on the results of an interview with one of the physics teachers at the school, it is known that students do not like physics lessons because physics lessons are very difficult to understand both conceptually and using formulas. The results of the preliminary study showed that around $61.29 \%$ of students understood mathematical representations, $6.45 \%$ of students understood graphical representations, $16.12 \%$ of students understood image representations, and $16.12 \%$ of students understood verbal representations. Students tend to memorize existing formulas in physics without knowing the correct concept of learning physics. Students when faced with representations of problems in the form of graphics, pictures and verbal students do not understand this representation.

There is a need for a paradigm shift in teaching and learning activities in the classroom. According to Ngalimun and Salabi (2016) a change in the learning paradigm will make a change in the center (focus) of learning from teacher-centered learning to student-centered learning. The way that can be applied to change the teaching and learning system in the classroom to make it more effective is to apply an appropriate learning model and is assisted by multiple representations that can overcome students' different representational abilities.
According to Joyce, et al (2009) the learning model is a learning model used by teachers to help students get or obtain information, ideas, skills, ways of thinking, and expressing their own ideas. One learning model that can be used to motivate students to improve their learning outcomes and problem solving abilities is the inquiry training learning model. Inquiry training learning model is a learning model that trains students to learn from facts to theory. According to Sihaloho, et al (2017) the purpose of inquiry training learning is to help students develop discipline and build the intellectual skills needed to ask questions and find answers based on their curiosity. Multirepresentation is re-representing the same concept with different representations, namely verbal, image and graphical representations, and mathematics (Waldrip, et al. 2010).

This research is also supported by the results of research conducted by Habibah and Bunawan (2018) proving that Inquiry Training learning can significantly improve learning outcomes and problem solving abilities. Not only that, Marpaung and Simanjuntak (2018) prove that the application of various forms of representation makes it easier for students to identify, understand, analyze, evaluate, and construct arguments, solve problems, can face various challenges, and then make decisions on physics problems.

\section{Research Method}

This research was conducted at Senior High School 17 Medan and the implementation time was from July to August in the first semester of the 2019/2020 school year. The population in this study were all class XI students of Senior High School 17 Medan in the 2019/2020 academic year, totaling 5 classes. The sample in this study consisted of two classes selected by side random cluster. The class sample was taken from the population, namely 2 classes, each of which consisted of 30 students, one class was used as an experimental class by applying the inquiry training learning model with multiple representations and the other class being used as a control class using conventional 
learning models. This type of research is a quasi experiment with the research design as shown in Table 1.

Table 1.Two group pretest-posttest design

Class Pretest Treatment Postest

\begin{tabular}{cccc}
\hline Experiment & $\mathrm{Y}_{1}$ & $\mathrm{X}_{1}$ & $\mathrm{Y}_{2}$ \\
Control & $\mathrm{Y}_{1}$ & $\mathrm{X}_{2}$ & $\mathrm{Y}_{2}$ \\
\hline
\end{tabular}

Information:

$\mathrm{Y}_{1}$ : initial ability test (pretest)

$\mathrm{Y}_{2}$ : final proficiency test (posttest)

$\mathrm{X}_{1}$ : learning with Inquiry Training with multiple representations

$\mathrm{X}_{2}$ : Learning with conventional models

Before carrying out learning activities, a preliminary test was carried out in the control class and the experimental class. The instrument used was a multiple choice test of 10 questions for learning outcomes and an essay test of 5 questions for problem-solving abilities in the subject of Elasticity and Hooke's Law which had been validated by the validator. After the pretest data was obtained, data analysis was carried out using normality test, homogeneity test and initial hypothesis test to determine students' initial ability in learning outcomes and problem-solving abilities were the same. The difference in learning outcomes and students' final problem-solving abilities in the experimental class and the control class can be seen by doing a post-test and then analyzed using the t-test.

\section{Result and Discussion}

\section{a. Result}

The data described in this study include learning outcomes and students' problem solving abilities in the subject of Elasticity and Hooke's Law, which were given different treatments, namely 1) inquiry training learning model with multiple representations, 2) conventional learning models. The results of the pretest data for the experimental class and control class students for learning outcomes can be seen in Table 2.
Table 2. Data on pretest learning outcomes

\begin{tabular}{|c|c|c|c|c|c|}
\hline \multicolumn{3}{|c|}{ Experiment Class } & \multicolumn{3}{|c|}{ Control Class } \\
\hline $\begin{array}{l}\text { Value } \\
\text { Interval }\end{array}$ & f & Average & $\begin{array}{l}\text { Value } \\
\text { Interval }\end{array}$ & $\mathrm{f}$ & Average \\
\hline $10-18$ & 5 & \multirow{6}{*}{33.00} & $10-18$ & 6 & \multirow{6}{*}{30.00} \\
\hline $19-27$ & 5 & & $19-27$ & 6 & \\
\hline $28-36$ & 7 & & $28-36$ & 7 & \\
\hline $37-45$ & 5 & & $37-45$ & 5 & \\
\hline $46-54$ & 5 & & $46-54$ & 5 & \\
\hline $55-63$ & 3 & & $55-63$ & 1 & \\
\hline
\end{tabular}

The results of the pretest data on students' problem solving abilities in the experimental class and control class can be seen in Table 3.

Table 3.Data on the problem solving ability pretest

\begin{tabular}{|c|c|c|c|c|c|}
\hline \multicolumn{3}{|c|}{ Experiment Class } & \multicolumn{3}{|c|}{ Control Class } \\
\hline $\begin{array}{l}\text { Value } \\
\text { Interval }\end{array}$ & $\mathrm{f}$ & Average & $\begin{array}{l}\text { Value } \\
\text { Interval }\end{array}$ & $\mathrm{f}$ & Average \\
\hline $20-22$ & 4 & & $20-22$ & 5 & \\
\hline $23-25$ & 9 & & $23-25$ & 12 & \\
\hline $26-28$ & 7 & 26.22 & $26-28$ & 5 & 25.26 \\
\hline $29-31$ & 4 & & $29-31$ & 5 & \\
\hline $32-34$ & 6 & & $32-34$ & 3 & \\
\hline
\end{tabular}

Based on Table 2 and Table 3, it shows that the pretest data for the two classes can be visualized in Figure 1 for learning outcomes and Figure 2 for problemsolving abilities.

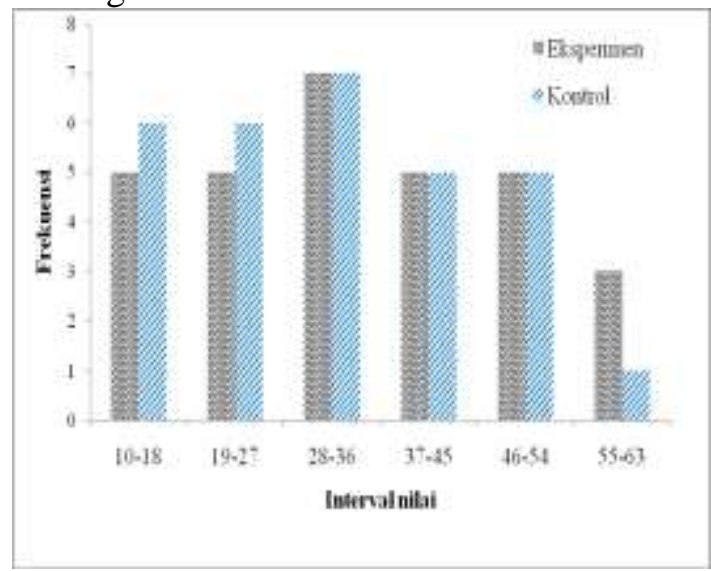

Figure 1 Pretest Data Bar Diagram for Experiment Class and Control Class for learning outcomes 


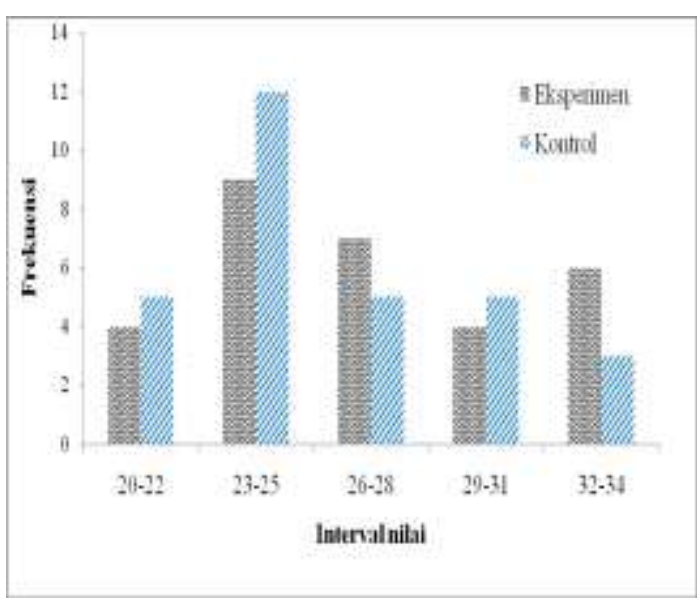

Figure 2.Data Bar Diagram Pretest problemsolving abilities

The results of the posttest data on the learning outcomes of the experimental class and control class can be seen in Table 4.

Table 4. Post-test data on learning outcomes

\begin{tabular}{|c|c|c|c|c|c|}
\hline \multicolumn{3}{|c|}{ Experiment Class } & \multicolumn{3}{|c|}{ Control Class } \\
\hline $\begin{array}{l}\text { Value } \\
\text { Interval }\end{array}$ & $\mathrm{f}$ & Average & $\begin{array}{l}\text { Value } \\
\text { Interval }\end{array}$ & $\mathrm{f}$ & Average \\
\hline $40-49$ & 2 & \multirow{7}{*}{33.00} & $20-29$ & 1 & \multirow{7}{*}{30.00} \\
\hline $50-59$ & 3 & & $30-39$ & 1 & \\
\hline $60-69$ & 7 & & $40-49$ & 3 & \\
\hline $70-79$ & 7 & & $50-59$ & 6 & \\
\hline $80-89$ & 6 & & $60-69$ & 9 & \\
\hline $90-99$ & 3 & & $70-79$ & 6 & \\
\hline 100-109 & 2 & & $80-89$ & 4 & \\
\hline
\end{tabular}

The results of the posttest data on the problem solving ability of the experimental class and control class can be seen in Table 5.

Table 5: Posttest data on problem-solving abilities

\begin{tabular}{|c|c|c|c|c|c|}
\hline \multicolumn{3}{|c|}{ Experiment Class } & \multicolumn{3}{|c|}{ Control Class } \\
\hline $\begin{array}{l}\text { Value } \\
\text { Interval }\end{array}$ & $\mathrm{f}$ & Average & $\begin{array}{l}\text { Value } \\
\text { Interval }\end{array}$ & $\mathrm{f}$ & Average \\
\hline $55-58$ & 0 & \multirow{7}{*}{26.22} & $55-58$ & 6 & \multirow{7}{*}{25.26} \\
\hline $59-62$ & 1 & & $59-62$ & 5 & \\
\hline $63-66$ & 3 & & $63-66$ & 6 & \\
\hline $67-70$ & 4 & & $67-70$ & 6 & \\
\hline $71-74$ & 8 & & $71-74$ & 4 & \\
\hline $75-79$ & 7 & & $75-79$ & 3 & \\
\hline $80-83$ & 7 & & $80-83$ & 0 & \\
\hline
\end{tabular}

Based on Table 3 and Table 4, it shows that the post-test data of the two classes can be visualized in Figure 3 for learning outcomes and Figure 4 for problemsolving abilities.

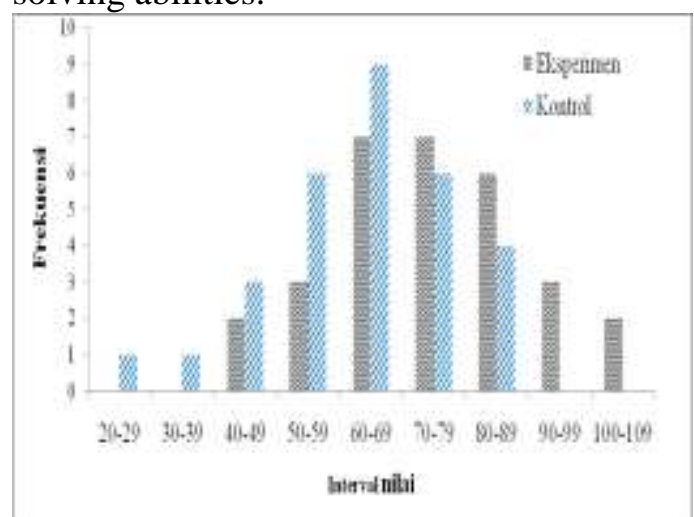

Figure 3. Posttest Data Bar Diagram for Learning Outcomes

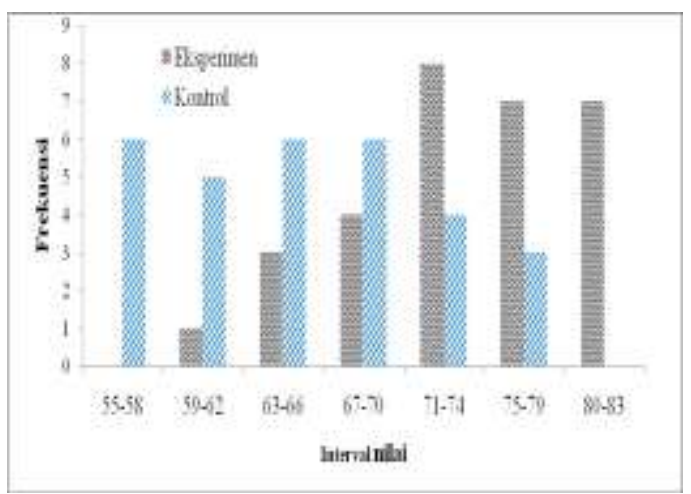

Figure 4. KPM Post-Test Data Bar Diagram

The normality test aims to see whether the sample is normally distributed or not using the Liliefors test. The testing criteria are if the Lhitung $<$ Ltabel, then the data is normally distributed. The results of the pretest data normality test of the experimental and control class learning outcomes are presented in Table 6.

Table 6. Data Normality Test of Learning Outcomes Pretest

\begin{tabular}{llll}
\hline Class & $\mathrm{L}_{\text {hitung }}$ & $\mathrm{L}_{\text {tabel }}(\alpha=0,05)$ & Conclusion \\
\hline Experiment & 0.1421 & 0.1610 & Normal \\
\hline Control & 0.1486 & 0.1610 & Normal \\
\hline
\end{tabular}


The results of the pretest data normality test of the experimental and control class learning outcomes are stated in Table 7.

Table 7. Normality Test of Learning Outcomes Post-Test Data

\begin{tabular}{llll}
\hline Class & $\mathrm{L}_{\text {hitung }}$ & $\mathrm{L}_{\text {tabel }}(\alpha=0,05)$ & Conclusion \\
\hline Experiement & 0.1413 & 0.1610 & normal \\
\hline Control & 0.1229 & 0.1610 & normal \\
\hline
\end{tabular}

Table 6 and Table 7 show that Lhitung < Ltabel, it can be concluded that the pretest and posttest data on the learning outcomes of both classes comes from a population that is normally distributed.

The results of the pretest data normality test of the experimental and control class problem-solving abilities are stated in Table 8.

Table 8. Normality Test of KPM Pretest Data

\begin{tabular}{llll}
\hline Class & $\mathrm{L}_{\text {hitung }}$ & $\mathrm{L}_{\text {tabel }}(\alpha=0,05)$ & Conclusion \\
\hline Experiement & 0.1229 & 0.1610 & normal \\
\hline Control & 0.1538 & 0.1610 & normal \\
\hline
\end{tabular}

The results of the post-test data normality test of the experimental and control class problem-solving abilities are stated in Table 9.

Table 9. KPM Post-Test Data Normality Test

\begin{tabular}{llll}
\hline Class & $\mathrm{L}_{\text {hitung }}$ & $\mathrm{L}_{\text {tabel }}(\alpha=0,05)$ & Conclusion \\
\hline Experiement & 0.1093 & 0.1610 & normal \\
\hline Kontrol & 0.1461 & 0.1610 & normal \\
\hline
\end{tabular}

Tabel 8 dan Tabel 9 menunjukkan bahwa $\mathrm{L}_{\text {hitung }}<\mathrm{L}_{\text {tabel }}$ dapat disimpulkan bahwa data pretes dan postes kemampuan pemecahan masalah kedua kelas berasal dari populasi yang berdistribusi normal.

Pengujian homogenitas dilakukan dengan uji $\mathrm{F}$ untuk mengetahui kelas sampel berasal dari populasi yang homogen atau tidak, artinya sampel yang dipakai dalam penelitian ini dapat mewakili seluruh populasi yang ada. Data dikatakan homogen memiliki kriteria apabila $F_{\text {hitung }}<\mathrm{F}_{\text {tabel }}$. Secara ringkas hasil perhitungan uji homogenitas data pretes hasil belajar kedua kelas ditunjukkan pada Tabel 10.

Table 10. Homogeneity Test of Learning Outcomes Pretest Data

\begin{tabular}{|c|c|c|c|c|}
\hline Data & Varians & $\mathrm{F}_{\text {hitung }}$ & $\mathrm{F}_{\text {tabel }}$ & Conclusion \\
\hline \multirow{2}{*}{ Experiement } & 256.2 & \multirow{4}{*}{1.16} & \multirow{4}{*}{1.86} & \multirow{4}{*}{ homogen } \\
\hline & 1 & & & \\
\hline \multirow{2}{*}{ Control } & 220.6 & & & \\
\hline & 9 & & & \\
\hline
\end{tabular}

The results of the calculation of the homogeneity test of the post-test data on the learning outcomes of the two classes are shown in Table 11.

Table 11. Homogeneity Test of Learning Outcomes Post-Test Data

\begin{tabular}{lllll}
\hline Data & Varians & $\mathrm{F}_{\text {hitung }}$ & $\mathrm{F}_{\text {tabel }}$ & Conclusion \\
\hline Experiement & 251.6 & & & \\
& 1 & & & \\
\cline { 1 - 2 } Control & 221.2 & & 1.13 & homogen \\
& 6 & & & \\
\hline
\end{tabular}

Table 10 and Table 11 show that the data obtained is homogeneous or can represent the entire population.

In summary, the results of the calculation of the pretest data homogeneity test of the problem-solving abilities of the two classes are shown in Table 12.

Table 12. Homogeneity Test of KPM Pretest Data

\begin{tabular}{|c|c|c|c|c|}
\hline Data & Varians & $F_{\text {hitung }}$ & $\mathrm{F}_{\text {tabel }}$ & Conclusion \\
\hline Experiement & 16.82 & \multirow{2}{*}{1.25} & \multirow{2}{*}{1.86} & \multirow{2}{*}{ homogen } \\
\hline Control & 13.45 & & & \\
\hline
\end{tabular}


Table 13. Homogeneity Test of KPM PostTest Data

\begin{tabular}{lcccc}
\hline Data & Varians & $\mathrm{F}_{\text {hitung }}$ & $\mathrm{F}_{\text {tabel }}$ & Conclusion \\
\cline { 1 - 2 } Experiement & 51.34 & \multirow{2}{*}{1.30} & 1.86 & homogen \\
\cline { 1 - 2 } Control & 39.42 & & & \\
\hline
\end{tabular}

Table 12 and Table 13 show that the data obtained is homogeneous or can represent the entire population.

The pretest data hypothesis testing was carried out using the $t$ test. The $t$ test on the pretest data was carried out to determine the students' initial ability, there was no significant difference. Hypothesis testing of the pretest learning outcomes data is shown in Table 14.

Table 14. Summary of the t-test calculation of data pretest learning outcomes

\begin{tabular}{lcccl}
\hline Data & Average & $\mathrm{t}_{\text {count }}$ & $\mathrm{t}_{\text {table }}$ & Conclusion \\
\cline { 1 - 2 } Experiement & 33.00 & \multirow{2}{*}{0.753} & 2.002 & $\begin{array}{l}\text { Both classes } \\
\text { have the same } \\
\text { initial abilities. }\end{array}$ \\
\hline Control & 30.00 & & &
\end{tabular}

Table 14 shows that for the pretest data ttable <tcount, namely $-2.002<0.753$ $<2.002$, it can be concluded that students 'initial abilities in the experimental class were significantly the same as students' initial abilities in the control class.

Hypothesis testing of post-test data on learning outcomes of both classes is shown in Table 15.

Table 15. Summary of t-test calculations Post-test data learning outcomes

\begin{tabular}{|c|c|c|c|c|}
\hline Data & $\begin{array}{l}\text { Rata- } \\
\text { rata }\end{array}$ & $\mathrm{t}_{\text {hitung }}$ & $\begin{array}{l}\mathrm{t}_{\text {tabel }} \\
(\alpha= \\
0,05)\end{array}$ & Conclusion \\
\hline $\begin{array}{l}\text { Experiem } \\
\text { ent }\end{array}$ & 69.67 & & & $\begin{array}{l}\text { There is a } \\
\text { significant }\end{array}$ \\
\hline Control & 58.33 & $\begin{array}{l}2.86 \\
3\end{array}$ & 2.002 & $\begin{array}{l}\text { effect of the } \\
\text { training } \\
\text { inquiry } \\
\text { model with } \\
\text { multiple } \\
\text { representati } \\
\text { ons on } \\
\text { learning } \\
\text { outcomes }\end{array}$ \\
\hline
\end{tabular}

Based on Table 15, it is obtained from post-test data tcount> ttable, namely $2.863>2.002$. It can be concluded that the average value of the experimental class learning outcomes is significantly greater than the average value of the control class learning outcomes or there is a significant effect of the inquiry training learning model with multiple representations on student learning outcomes.

Hypothesis testing of pretest data on problem solving abilities is shown in Table 16.

Table 16. Summary of the t-test calculation of data pretest problem solving ability

\begin{tabular}{lllll}
\hline Data & $\begin{array}{l}\text { Rata- } \\
\text { rata }\end{array}$ & $\mathrm{t}_{\text {hitung }}$ & $\mathrm{t}_{\text {tabel }}$ & $\begin{array}{l}\text { Kesimpul } \\
\text { an }\end{array}$ \\
\hline Experiment & 26.22 & & & $\begin{array}{l}\text { Both } \\
\text { classes } \\
\text { have the } \\
\text { Control }\end{array}$ \\
\hline 25.26 & 6 & 2 & $\begin{array}{l}\text { same } \\
\text { initial } \\
\text { abilities. }\end{array}$ \\
\hline
\end{tabular}

Table 16 shows that for the pretest data ttable <tcount, namely $-2.002<0.956$ $<2.002$, it can be concluded that students 'initial abilities in the experimental class were significantly the same as students' initial abilities in the control class.

Hypothesis testing of post-test data on problem-solving abilities is shown in Table 17.

Table 17. Summary of the t-test calculation of data posttest problem solving ability

\begin{tabular}{lllll}
\hline Data & $\begin{array}{l}\text { Rata- } \\
\text { rata }\end{array}$ & $\mathrm{t}_{\text {hitung }}$ & $\mathrm{t}_{\text {tabel }}$ & Kesimpulan \\
\hline Experiment & 74.52 & & & $\begin{array}{l}\text { There was a } \\
\text { significant } \\
\text { effect of the } \\
\text { training }\end{array}$ \\
& & & & $\begin{array}{l}\text { inquiry } \\
\text { model with } \\
\text { Control }\end{array}$ \\
& 65.48 & 5 & 2.00 & $\begin{array}{l}\text { multiple } \\
\text { representatio } \\
\end{array}$ \\
& & & & $\begin{array}{l}\text { ns on } \\
\text { learning } \\
\end{array}$ \\
& & & & outcomes \\
\hline
\end{tabular}

Based on Table 17, posttest tcount> ttable, namely 5.225> 2.002. From these differences in value it can be concluded that the average value of learning outcomes and problem solving abilities of experimental class students is significantly greater than 
the average value of the control class or there is a significant difference from the inquiry training learning model with multiple representations of learning outcomes and student problem solving abilities in the subject matter of Elasticity and Hooke's Law Senior High School 17 Medan. The graph of the average student activity observation for each meeting is shown in Figure 5.

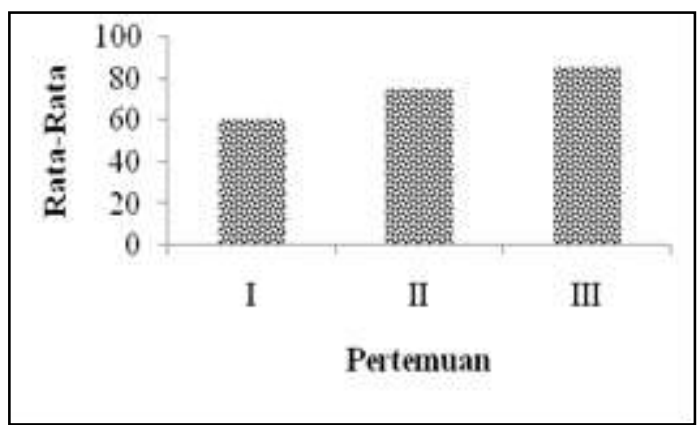

Figure 5. Increasing Student Activity for Each Meeting

The learning activities of the experimental class students increased from the first meeting to the third meeting. At the first meeting 61.23 (less active), the second meeting 74.86 (active), and the third meeting 85.97 (very active). Relevant research was conducted by Sihaloho, et al (2017) that the inquiry training learning model can increase student activity and learning outcomes.

The graph of the average observation for each training inquiry indicator at each meeting is shown in Figure 6.

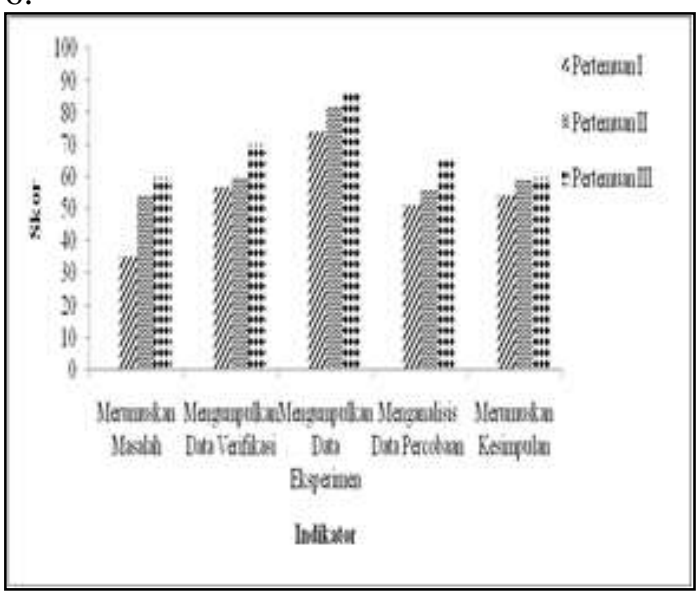

Figure 6. Improved learning outcomes of inquiry training based on indicators
There was an increase in the percentage of each training inquiry indicator at each meeting because it was given the treatment of the training inquiry model with multiple representations. With the multirepresentation ability combined with the inquiry training model, it is very influential on student learning outcomes. The ability to represent problems really helps students in solving problems in learning.

There are 5 indicators for problem solving abilities consisting of identifying relevant concepts, planning problem-solving strategies, implementing problem-solving strategies, and evaluating solutions. The KPM indicator score for each question can be seen in Table 18.

Table 18. Score of KPM indicator for each question

\begin{tabular}{llllll}
\hline & \multicolumn{7}{l}{ Question } \\
\cline { 2 - 6 } Indicator & 1 & 2 & 3 & 4 & 5 \\
\hline \multirow{2}{*}{ Identify relevant concepts } & 0 & 0 & 0 & 0 & 0 \\
\hline Planning problem solving & 6 & 5 & 5 & 5 & 4 \\
strategies & 0 & 5 & 9 & 7 & 2 \\
\hline Implement problem solving & 7 & 6 & 7 & 7 & 5 \\
strategies & 6 & 7 & 3 & 2 & 3 \\
\hline \multirow{2}{*}{ Evaluating solutions } & 2 & 1 & 2 & 2 & \\
\hline
\end{tabular}

Based on the indicator analysis, each indicator has increased. This is in accordance with the research of Solihah, et al. (2018) that the use of multiple representations can improve students' problem solving abilities. This is because representation in learning can train students to study their own thinking patterns to build concepts, from what the teacher says in learning by developing representation skills.

\section{b. Disscusion}

The normality test and homogeneity test can be seen that the data is normally distributed and homogeneous, then the data is then tested for the hypothesis. Hypothesis testing in this study used t-test analysis, based on the results of hypothesis testing, it was found that there were differences in learning outcomes and students' problem 
solving abilities using the inquiry training learning model with multi-representation with conventional learning. The results of this study are in line with the results of research conducted by several previous researchers who have shown a positive impact on the effect of inquiry training learning with multiple representations. Habibah and Bunawan (2018) said that the learning outcomes of students who were treated with the implementation of the inquiry training learning model with a multirepresentational approach on the subject matter of business and energy had increased. This is also in line with the research of Prahani, et al. (2016) showing that multirepresentation-based physics learning is effective in training students' representation skills. The learning process in the teacher's classroom should be able to maximize the use of various representations in explaining a concept, not only verbal and mathematical representations but also image and graphic representations to train students' representation skills which are of course very useful in learning physics. Multiple representations are used to make it easy for students to understand a concept given through various types of representations. This is in line with the research of Widyatingtiyas, et al. (2015) which states that multiple representations can support one's understanding of information. Where everyone has their respective intelligence, so they need different views of the information obtained to make it easier to understand. This occurs because inquiry training learning requires students to be more active in seeking and understanding the information obtained and connecting it in everyday life in every activity designed at the learning stage.

The results of the problem-solving ability test consist of five aspects of identifying relevant concepts, planning problem-solving strategies, implementing problem-solving strategies, and evaluating solutions. The indicator that has increased is planning problem-solving strategies. The main factor that causes an increase in this indicator is the illustration of daily life related to the material being taught. When the first phase was carried out, many students asked the teacher questions during the second phase.

The advantage in the second phase is that it trains students to collect verification data about events they see / observe which can also train students' ability to observe or observe an event grouping / classifying the information they have obtained and the answers given by the teacher are limited to yes or no words. so that students feel challenged to find the answer. In the formulation of problems students can relate the concepts and knowledge they already have with new concepts and knowledge they find through the process of assimilation and accommodation, so that students themselves build knowledge until a concept is formulated in themselves. The information obtained is used as a basis for formulating problems so as to improve student learning outcomes in formulating problems.

The third phase has the advantage that students will be trained to design experiments and use the tools / materials and resources they get from the previous phase and students can determine patterns and relationships between the variables contained in the experiment. Students are given the opportunity to carry out experiments where they answer problems given by the teacher through experiments so that in this phase measuring and calculating on the indicator of problem solving ability has increased due to the treatment given in the third phase. In addition, students discover and build their own knowledge.

Fase keempat melatih siswa mengolah dan memformulasikan suatu penjelasan yang mereka dapat baik dari eksperimen maupun dari hasil pengalaman dan pemikiran siswa. Partisipasi dalam kegiatan eksperimen melatih siswa menjelaskan dan mengidentifikasi variabel yang melibatkan kemampuan pemecahan masalah siswa. Siswa dapat dilatih untuk menghubungkan hasil pengamatan serta menemukan pola atau keteraturan dari hasil pengamatan yang ditemukan untuk menarik kesimpulan pada fase keempat yaitu mengevaluasi solusi. Semua aktivitas ini mendukung pengembangan kemampuan pemecahan masalah yaitu merumuskan kesimpulan dari pembelajaran. 
Increasing the problem-solving abilities of students who are taught using the inquiry training learning model with multiple representations is better than conventional learning, so this research is in line with research conducted by Habibah and Bunawan (2018) which states that student learning outcomes are treated with the implementation of the inquiry training learning model with the approach multi representation on the main subject of business and energy has increased. This is also in line with the research of Prahani, et al. (2016) showing that multi-representationbased physics learning is effective in training students' representation skills. The learning process in the teacher's classroom should be able to maximize the use of various representations in explaining a concept, not only verbal and mathematical representations but also image and graphic representations to train students' representation skills which are of course very useful in learning physics.

The constraints faced by researchers are the number of students from each group is 6 people so that some students are less effective when working in their group and do not get maximum attention and supervision in carrying out activities, researchers are still lacking in class control so that when learning often experiences a lack of time and availability practicum equipment is not proportional to the number of student groups so to overcome this the researcher has to add equipment from the laboratory and make simple tools related to the material to be taught and the unavailability of projectors in the classroom.

\section{Conclusion}

Based on the results of the research conducted, it was found that there was a difference which was a significant influence of the inquiry training learning model with multiple representations on student learning outcomes and problem-solving abilities on the subject of Elasticity and Hooke's Law in class XI SMA Negeri 17 Medan.

\section{Suggestion}

Based on the conclusions that have been put forward, according to the results of the research obtained at Senior High School 17 Medan, the researcher provides suggestions to the next researcher: 1) to minimize the number of students in each group so that they are more effective in delivering material and can better supervise practicum activities carried out by students , 2) further researchers are expected to master classroom management so that students who are noisy in the classroom can be controlled and the delivery of learning material can be conveyed properly, 3) the next researcher must make simple tools and practicum regarding the material to be taught to anticipate the availability of practical tools and materials. which will be used and reproduce student worksheets if a projector is not available in the classroom.

\section{Reference}

Habibah, S. dan Bunawan, W., (2018), Implementasi pendekatan multi representasi Pada Model Pembelajaran inquiry training untuk meningkatkan hasil belajar siswa pada materi pokok usaha dan energi, Jurnal Penelitian Bidang Pendidikan, 24(1), 28-37.

Joyce, B., Weil, M., dan Calhoun, E., (2009), Model-Model Pengajaran Edisi Delapan, Pustaka Belajar, Yogyakarta.

Marpaung, N. dan Simanjuntak, M. P., (2018), 'Desain pembelajaran berbasis masalah dan multipel representasi terhadap hasil belajar dan keterampilan berpikir kritis', INPAFI (Inovasi Pembelajaran Fisika), 6(3), 40-45.

Ngalimun, F., M., dan Salabi, A., (2016), Strategi dan model pembelajaran. Yogyakarta, Aswaja Pressindo. 
Prahani,B., Limatahu, I., Soegimin, W., Yuanita, L dan Nur, M., (2016), 'Effectiveness of physics learning material through guided inquiry model to improve student's problem solving skills based on multiple representation', International Journal of Education and Research, 4(12), 231-242.

Sanjaya, W., (2006), Strategi Pembelajaran Berorientasi Standar Proses Pendidikan, Jakarta : Kencana Prenadamedia Group.

Sihaloho, R. R, Sahyar, dan Ginting, E. M., (2017), The effect of problem based learning (pbl) model toward student's creative thinking and problem solving ability in senior high school, IOSR Journal of Research \& Method in Education (IOSR-JRME), 7(4), 1118.

Solihah, A., Sinaga, P. dan Amsor., (2018), 'Multirepresentasi momentum dan impuls untuk meningkatkan kognitif dan kemampuan pemecahan masalah siswa SMA', Seminar Nasional Quantum, ISSN : 2477-1511, 338-344.

Waldrip, B., Prain, V., and Carolan, J., (2010), Using multi-modal representations to improve learning in junior secondary science, Res. Science Education, 40(1) : 65-80.

Widianingtiyas, L., Siswoyo, S. dan Bakri, F., (2015), 'Pengaruh pendekatan multi representasi dalam pembelajaran fisika terhadap kemampuan kognitif siswa SMA', Jurnal Penelitian \& Pengembangan Pendidikan Fisika, 1(1), 31-38. 